FACTA UNIVERSITATIS

Series: Philosophy, Sociology, Psychology and History Vol. 18, N² 2, 2019, pp. 105 - 113

https://doi.org/10.22190/FUPSPH1902105S

Review Paper

\title{
WEDDING AS A GENERAL PATTERN OF CELEBRATION IN SERBS
}

\author{
UDC 392.51 $(=163.41)$
}

\begin{abstract}
Žikica Simić
Niš

Abstract. In this paper, the author deals with the contemporary festive culture of the Serbian people reflected in various forms of irrationality - above all immodesty, uncontrollability and wastefulness. The author shows how a wedding, as the main Serbian custom, becomes a general pattern of celebration and how this model is transmitted onto all other holidays - both private (family and personal) events and those collective events such as national and local holidays (religious and state holidays).
\end{abstract}

Key words: wedding, Serbian people, patron saint, slava, funeral, immodesty

\section{INTRODUCTION}

Serbs are certainly not a people inclined to the Apollonian principle of moderation, but to the principle of Dionysian uncontrollability and unrestraint, which is the exact opposite of the former - in behavior, in feelings, in the way of celebrating their family, personal, religious, national holidays and events. According to the famous Serbian ethnologist, Sreten Petrović, the Serbian people are characterized by a traditional tendency to transform all their festivities into ritual, pomp and celebration: a celebration of everything. Serbian spirituality is a machine that turns everything into a ritual. The Serbian people seem to need spectacle in everything (Petrović 2000, 51, 68). This is evident when one celebrates the most joyous life cycle events such as birth and wedding, and commemorates a significant event such as a death. Of all customs, the wedding is the most important one for Serbs. This can be deduced from the dominance of grandeur and splendor incorporated in the celebration, and in certain areas of Serbia this type of celebration has acquired certain peculiarities through time which in turn depend on the cultural level these areas have reached. "The wedding is the dominant form of celebration, and the tendency to turn every ceremony and celebration into a wedding ceremony indicates an emphasized line of mentality of the Serb population in central and southern Serbia. Particularly expressed in

Received October 3, 2019 / Accepted October 14, 2019

Corresponding author: Žikica Simić

18000 Niš, Serbia

E-mail: zikicasimic@yahoo.com 
the wedding ceremony is irrational wasting as well as at other festivals (...)" (Jovanović 2008, 266).

\section{WEDDING TRANSFORMATION AND CULTIVATION}

Weddings have always been both a domestic and a national carnival when forbidden and undesirable behavior becomes temporarily allowed, when rules of social conduct are broken and boundaries exceeded. On these occasions, women were allowed to dress more freely, and men were allowed to engage in drunkenness, breaking bottles and firing rifles and pistols. "Apart from the usual and standardized rules, every culture allows or permits different and forbidden behavior during certain holidays and rituals. The unusual practices of Serbian wedding guests, competing in unrestricting, uncontrolled and unreasonable acts, were allowed as part of a wedding rite. (...) The history of fashion, play and culture is a history of transgressing the boundaries of decency and liberation from taboo rules, which later became an essential part of the official culture." (Jovanović 2009 , 174). However, what is very characteristic for Serbian weddings and other holiday celebrations is the fact that while adopting new cultural contents through innovations and modifications, these celebrations simultaneously retain some of the old pagan customs. It is this pagan element that is the main cause of immoderate behavior and the factor that significantly determines not only the festive but also the general culture of the Serbian people. Thus, such uncontrollability displayed in the manners of celebration and behavior of Serbs is more related to stagnation and conservativism in behavior patterns than to evolution and innovation in customs.

Although weddings were conducted in a rather primitive way in the past ${ }^{1}$, today's weddings are significantly different from the former, traditional ones. It can be said that they have acquired a significant level of cultivation, becoming more refined than they were decades ago. The wedding itself, as well as other family celebrations (not only of joy but also mourning), have undergone a significant transformation over the last few decades during the transitional period of Serbian society. Many wedding customs, with all their variety and specificity, "seem to be dying out as a result of the on-going process of modernization. Accordingly, wedding practices may change under (...) external influence. Today's customs are rather different from those practiced fifty years ago" (Vlajković i Stamenković 2012, 281). Many bad customs, including those unacceptable and inapplicable to today's conditions of modern and urban life, have disappeared or have been modified. Former arrogance is no longer present. This arrogant attitude was evident in situations when a wedding guest harassed others by ordering the wedding band to play his favorite music, thus selfishly imposing his musical taste (or rather distaste) onto others. The wedding music repertoire itself has become more diverse and somewhat more sophisticated, since it no longer consists of folk and turbo folk songs of the most disgusting and kitsch type. Weddings are no longer celebrated in barracks in one's own backyard or tents temporarily installed on busy roads, but in restaurants specifically

\footnotetext{
${ }^{1}$ What was allowed in the tradition of the Serbs was the inappropriate behavior characteristic of the wedding guests. In his concise description of a wedding, Vuk Karadzić emphasizes precisely this behavior: The wedding guests are so problematic and cheeky that there is a comparison which reads "like Serbian wedding guests". They slaughter hens and pigs, slaughter turkeys, geese and ducks; they break vessels for beverages, steal spoons; they (like in Bačka) pull the car to the top of the house, pour themselves drinks, drink, shout out, clap (Karadžić 1969,172).
} 
designed for these occasions where, instead of relatives and neighbors, professional caterers serve the guests. It has long since become unthinkable for the best man, once an undisputed "commander" at the wedding, to chimerically impose his own will onto other guests and musicians by determining the time when meals were to be served and how long the wedding reception was to last. Equally unthinkable is the custom of climbing onto benches and tables to dance during these types of celebrations. The Serbs were also in the habit of engaging in physical altercations under the influence of alcohol, and sometimes even when sober. Modernization that occurs through the general transformation of Serbian society has, however, resulted in a certain higher degree of cultivation of the Serbian people so the above mentioned phenomena are occurring more rarely or are completely disappearing. However, there is a high amount of bad taste and general lack of moderation still present in these celebrations.

\section{TRANSMISSION OF THE UNCONTROLLABLE WEDDING RITUAL TO ALL OTHER FESTIVITIES AND RITUALS}

Likewise, the dangerous and arrogant habit of using firearms during a wedding reception was transferred to other family, national and religious holidays and celebrations of the joyful kind. The old ritual of firing weapons had its use rooted in the pagan belief that evil spirits can be cast away by this act. This later developed into a mere habit that was simply used to evoke pleasure from hearing gunshots. Weapons were fired to announce and celebrate the birth of one's son, to celebrate Christmas or to celebrate two New Years (the one celebrated the world over, and the Serbian Orthodox one fourteen day later). The Serbs, therefore, transferred the wedding pattern to all similar life events and festivities ${ }^{2}$, even to the less important moments such as elementary and secondary school finals ("matura") or the former departure to the conscriptory army which was replaced as soon as possible by a new and pompous celebration of coming of age (eighteenth birthday) as a kind of jubilee. This new ritual was devised to compensate for the loss after the abolishment of the conscriptory army and to avoid being deprived of one more holiday and feast day ${ }^{3}$. Serbs are still inclined to inappropriately celebrate even insignificant events such as buying a used car. Although they paid for it with their own money, they tend to organize parties to celebrate as if they had won it on the lottery. This ritualistic tendency to celebrate and organize parties used to be trivialized and abused by

\footnotetext{
${ }^{2}$ For example, Sirovari - a beautiful folk custom - is held in the south of Serbia. It is found in the villages of Preševo, Leksovačka Morava and Pčinja. The essence and purpose of the custom is to expel the karakondžula (kallikantzaros - a malevolent goblin in in Southeastern European and Anatolian folklore). In another version of the custom, it is a way of celebrating the Orthodox New Year (Đordjević, Uzunović i Petrović 2014, 119). The origin of this custom stems from wedding rituals: one sirovar man in that party always dresses as a bride, as a daughter-inlaw, followed by the groom and the wedding party (Đorđević i Petrović 2012, 225).

${ }^{3}$ Too much importance is attached to the eighteenth birthday (...). The legal age of 18 (...) is celebrated. This is not a crucial year in our lives. (...) The average person spends over one thousand euros to celebrate legal adulthood. And guests are invited in abnormal numbers (...). One would say that we have fallen under Western influence, but I think that we Serbs have taken this trend of arrogance to its utmost limits. I see younger teens celebrating birthdays year after year in this fashion. Birthdays have become our wedding preparations, but they also serve as a way to get money. I don't think I've ever spent as much money as I did in the period of constant eighteenth birthday parties (...). Truthfully speaking - there are also really humble but beautiful celebrations of legal age. However, we are constantly seeing kitsch celebrations of this type. (...). Belly dancers have, for some reason, recently become a major attraction at birthdays (https://megafon.co/18-rodjendan-u-srbiji/).
} 
those wanting to benefit from it. A custom arose to force people to organize parties or buy drinks for others to mark ephemeral occasions such as buying new shoes or a new jacket. Construction workers used a metaphorical phrase of "Your walls are dry" to subtly remind the host of the house to buy them a drink to celebrate the work done. When Serbs, usually gastarbeiters, encounter moderate and modest ways of celebration in Europe and the rest of the world, they often note with a tone of regret and pity in their voice that Europeans know not how to feast. The aforementioned opinions on European ways of celebration are most commonly found within the gastarbeiter community.

Serbs, Vlachs and Roma people ${ }^{4}$, themselves not at a high civilization level, are most prone to organizing grandiose and extravagant weddings and other celebratory parties. There is a general rule which states that where there is greater poverty there exists greater glamor. This exaggeration serves as a psychological mechanism to compensate for the poverty. "We have the need to impress others, to fascinate them with wealth we do not possess (...) I have noticed this behavior at various receptions organized by embassies on the occasion of their national holidays. The poor countries of Asia and Africa have often had richer receptions than the undeniably richer countries (...) a psychological phenomenon occurs: at all costs I must not fall behind and therefore I go beyond the limits of what is possible and permissible" (Marić 2009, 64). Admittedly, many are gastarbeiters who can afford it. "The online editions of our newspapers and magazines reveal a staggering number of news reports about frighteningly large and expensive gastarbeiter weddings. The newspaper front page (headline and deck) is dominated by information on how much the wedding cost or how much money the musicians earned (especially the gratuity), the number of invitees, folk singers. Particularly magnificent and widely known are weddings in the Braničevo district, and, by their glamor, and weddings in villages of the Negotin region do not fall far behind." (Marjanović 2010, 98).

Others of poorer status feel compelled to follow and imitate that standard, namely games of prestige and status, despite their limited financial capacity, as a result of the pressure and expectations of the environment. "Your Orthodox neighbor, if he does it in his home country, will have no fewer than 100 and a maximum of 200 guests. Especially expensive are the ceremonies and the leasing of the hall in special facilities for weddings and parties" (Đorđević 2016, 107).

\section{THE FAMILY SLAVA AND FUNERAL RITES AS WEDDINGS}

The situation is similar with Serbian slavas (a custom of celebrating the patron saint of the family). Many Serbian people avoid celebrating their slava in the year of the death of a household member, which is a complete misconception and practice. Such an opinion, or such a misconception, stems precisely from the wrong notion of celebrating slava in the same manner one celebrates weddings: with a rich feast and typical

\footnotetext{
${ }^{4}$ These peoples behave and live according to the saying: "The poor squander, and the rich save." "The Roma want to show themselves to others (...) this is not rational from the point of view of the individual, group and ethnic community. Many Roma, though miserable, are willing to sacrifice finances for daily living expenses and to plunge into financial hardship to make a grand feast, birthday or funeral, or to celebrate a sunnah (circumcision) or to buy a minor woman. If they were to invest some of that money into buying the right place to live or hygiene products for their household and make various repairs - a requirement of the future - or if they invested it in schooling, their position would be much better. Customs and traditions cannot be kept in a "primitive way". No nation should be a slave to the traditional way of life". (Đorđević 2003, 12)
} 
exaggerations in food and drink, somewhere with obligatory music ${ }^{5}$ (which on a regular basis does not have to be bad), as well as frequent violation of the fasting rules, which are seen as an obstacle to the spirit of Dionysian uncontrollability, because hosts feel ashamed and embarrassed when welcoming their guests with fasting food. A fact that is often overlooked is that a slava can also be marked in a moderate fashion and does not necessarily require a luxurious type of celebration. It can also be marked in such a manner that is appropriate and respectful to the period of mourning if a family member has died recently. "An Orthodox Serb will prepare during the whole year, even if he is poor, to celebrate his slava (...) richly and for several days (Ivkova slava). A neighbor for his slava can host a few dozen relatives, colleagues and next door neighbors. The "nouveau riche Serbs", who do not just hold on to tradition but tend to show off, celebrate slavas in taverns and hotels, which is an unprecedented sacrilege. ${ }^{6}$ People eat and drink to the fullest. The Orthodox Serb will inadvertently celebrate, in luxurious and perhaps inappropriate manner, the birth of a child, child's baptism in the Church - which is performed in infancy, not in early youth as is the case with the Reformed Protestants and finally the first birthday of the child. No one here can even try to calculate the number of invited guests and how much of their hard earned money is being spent on these occasions!" (Đorđevic 2016, 107).

It is similar with worship. Many people celebrate religious holidays outside of the places of worship, namely in attractive tourist centers, gyms, swimming pools, luxury restaurants and taverns, with the inevitable "glass of spirits" and the sounds of music that pierces the eardrums and invoke only the lowest passions and urges. "They cannot wait for the long festive church services to end so they can move on to the 'main' event - fun, pleasure, relaxation, eating and drinking (...) There is luxury and wealth even where there is otherwise great poverty (... )" (Bigović 2010, 63-64).

\footnotetext{
${ }^{5}$ Christmas and New Year holidays, when we are faced with the increasing use of pyrotechnics and the increasingly aggressive and widespread use of firecrackers, remind one of the words of Bishop Gregory of Zahum-Herzegovina. Namely, several years ago, during the celebration of St. Basil Ostroshki, the bishop drew the attention of parents to see what their children did and what kind of people they grew up into when they were taught to shoot, noting that shooting is not a Serbian custom, as it has been taught to us for generations. "So parents, instead of talking about St. Basil, I have to calm your kids that you taught to shoot and you haven't taught them anything else. Those who hold tents and cafes there, are they the most important ones today? Is that most important!? Now we want to highlight the tent and cafes and drinks!? Is that how we celebrate a patron saint!? And the priest is guilty! I'm guilty too! We must not let anything be more important than St. Basil today. And we let that happen. (...) It is not the Serbian custom to shoot. One knows when to shoot. So this is what we learned, "We are Serbs because we shoot!". We are Serbs, brothers and sisters, when we live in dignity, when we pray to God, when we have a heart that feels for others. When we have the capacity to remain silent, when we need to remain silent. When we know how to speak and when to speak (...). We need to be serious and responsible (...)" http://srbin.info/2017/01/03/vladika-grigorijeobjasnio-zasto-nikako-ne-smemo-da-pucamo-tokom-praznika-video/?lang=lat), 03.01.2017.

${ }^{6}$ With all due respect to the author's opinion, we still consider the family celebration of slavas outside of homes is a more complex and delicate matter of modern times and cannot be reduced to sacrilege - the need for showiness, prestige and exaggeration. Under the influence of strong modernization and urbanization, this custom is undergoing a strong modification. Namely, in more modern and urban areas, families are forced to relocate celebration of slavas outside of their houses because of the cramped living space of their homes and lack of time due to work (which was not the case in traditional families whose members, especially women, freely managed their time due to the different nature of work). All family holidays have undergone such a transformation, especially those that require more guests. This new trend is increasingly demonstrated by the understanding and sympathy on the part of the clergy of the Serbian Orthodox Church, allowing it in "exceptional cases" to recognize that God is the "God of living people" rather than residential objects, although it is unclear how one determines whether a particular case is a rule or an exception in which one must act differently from what the rule requires.
} 
Serbian writer Stevan Sremac wrote "Ivkova slava" as an illustrative example of how celebrating a slava in the old town of Niš can become unruly and be transformed into wedding-like feasting. "The unbridled power of the pagan spirit casts doubt upon the Serbian Orthodox Christian slava and the established manner in which it should be celebrated (...) so any overindulgence in feasting which lends a different character to the celebration can be considered an alteration and as an establishment of a different pattern in behavior" (Jovanović 2008, 261-262). Even the most famous guests, the heroes of the story of "Ivkova slava", personify the three principles of intemperance: It is the principle of excessive talkativeness and lying embodied in Kalča, the principle of overeating represented in Kurjak, and the principle of drunkenness embodied in Smuk. All these three principles are present in the host Ivko himself who, at the time of his slava, behaved differently. The celebration of the slava itself ends with two weddings - between Kurjak and the widow Sika, and the former actor Svetislav and Sika's daughter. "This celebration, which strives towards rashness, contestation and overstepping the existing boundaries, stems from a pattern of behavior at weddings. The writer effectively linked the uncontrolled and unbridled celebration of a slava and a wedding, showing their relatedness and the possibility that a slava can be an introduction to a wedding. What is traditionally allowed as the described type of mischievous behavior is characteristic, in fact, of the wedding, because the indiscretion of Ivko's guests is identical to the behavior of the wedding guests (...). The actualized wedding chaos during the slava resulted in a real wedding feast that ends this ceremony with marriages" (Jovanović 2008, 268).

Priests tend to exaggerate when, reacting to this hedonism and material impropriety and pointing out the essence, meaning and purpose of a slava, they emphasize that the most essential elements needed for commemorating it are: ritual grain and wine. This advice takes an extreme form which sometimes completely excludes the feasting table. The famous Serbian enlightener Dositej Obradović was the one who pointed out these negative aspects of celebratory manners in Serbian people. However, it was the priests who directly influenced the change of this custom. Suggestions they gave to the people were related to reducing the number of immodest rituals and to behaving rationally. Although the reforms implemented have laid down clear rules for the practice of a slava, it has evidently lost its binding character and given way to improvisations in the last centuries, as direct expressions of conscious and unconscious disrespect and disregard of the Christian tradition. Practicing a slava in his own way, the Serbian host transformed it into a folk Orthodox custom, which meant an overstatement of the feasting and social aspect of a slava, and neglect of the spiritual. In doing so, a slava was reduced to exceeding the limits in eating, drinking and speaking (Jovanović 2006, 600, 605). During the fasting periods and on weekly fasting days, Wednesdays and Fridays, celebrations of slavas was subordinated and subjected to the rules of fasting. However, by arbitrary interpretations these rules were trivialized, which introduced new and different celebratory customs. Thus, it was considered appropriate to serve non-fasting meals after sunset or that fasting rules could be ignored if important or distinguished guests were to arrive (Vukanović 2001, 431). Examples of extravagant feasting, the success of which was measured in the abundance of meals and the number of guests, have shaped a pattern of behavior inadequate for a slava. The tendency of celebrating a slava in an extravagant manner was criticized by both secular and ecclesiastical authorities in the $19^{\text {th }}$ century. The effort to suppress and limit this phenomenon was particularly accentuated in liberated parts of Serbia but also, to some degree, in part still under Ottoman and Austrian rule. 
Ignoring the regulations and reforms of St. Sava, Serbs spent vast amounts of money on celebrating slavas. Thus, during the reign of Danilo Janković, the bishop of Gornji Karlovac in 1762, and following the demands of Austrian authorities, celebration of slavas was reduced to its modest, liturgical basis (Jovanović 2006, 606).

This indecent celebration goes beyond the confines of the private home and family slava, and is transmitted to many public institutions. Even in schools, official educational institutions, the celebration of Saint Sava as the patron saint of the school tends to get out of control and take on the form and character of an inadequate and tasteless celebration. Fortunately, universities and some political parties of a highly civic orientation are immune to this religious kitsch. Not only slavas, but also pilgrimages sometimes lose their spiritual meaning and spiritual character and turn into mere tourist trips with the sole purpose of having fun ${ }^{7}$. Moreover, during major religious (and national) holidays, such as Easter and Christmas, the festive programme broadcast on the national television is more reminiscent of a New Year's celebration than adequately adapted and selected for these specific spiritual occasions. Instead of adequate religious and spiritual television shows, the RTS (Serbian National Television) programme scheme largely consists of, is even dominated by, fun and inappropriate contents of a cheap character in the form of outdated humorous series and shows with lascivious content.

Weddings are not the sole excuse for this kind of immoderation. Even events of lesser significance can serve the same purpose, for example, relocation to a new residential or non-residential building (not only private homes but also buildings of public institutions) ${ }^{8}$. All these celebrations are conducted in an extremely lavish and luxurious manner, a manner which exceeds the financial means of the person celebrating. "Serbs are not a disciplined people. We do not like strict standards and regulations. We would rather be disheveled, unconventional, relaxed, without self-control ("when it's a ball, it's a ball"). We also do the same with food, drink and even cigarettes (...). In our country, the prevailing custom is to eat and drink immoderately at weddings, slavas, funeral ceremonies and birthdays because the food and drinks are served in abundance and are free of charge" (Marić 2009, 24). A Serbian orthodox person loves to celebrate religious and state holidays, he spares no money on it, is not rational and does not think in advance, he is jolly and only wishes to enjoy himself (...) (Đorđević 2016, 108). Serbian weddings are predominantly big and expensive. People spiral into debt in order to organize a luxurious wedding so it could be the main topic of conversation among the locals for months ahead. Even though one does not have enough money, a wedding must be organized beyond one's financial means due to the expectations and pressure of others.

\footnotetext{
${ }^{7}$ In some places in Serbia pilgrimages to monasteries have become quite secular. Former spiritual pilgrimage was transformed into a regular tourist trip, monasteries with magnificent natural surroundings became sites for barbecuing in nature and field trips - a typical picnic (Marković, Gavrilović 2014: 258-259). And there is so much food and music at the celebration of religious holidays that it is reminiscent of a wedding (Milošević Radulović i Stjepanović Zaharijevski 2014, 245).

${ }^{8}$ Doctors, nurses, paramedics, and all other employees of the Emergency Center at the Niš Clinical Center, accompanied by a trumpet player, moved into a new building this morning. Emergency director Miodrag Lazić says such a moment is "fitting to be accompanied by music". As traditionally merry occasions in Serbia are celebrated with musicians and the sounds of brass instruments, but also with a drum that amplified the rhythm, employees left the old building, where they had spent 70 years, says Dr. Lazic. They, accompanied by the trumpet player, went to the new building in a procession-like manner which was recorded by cell phones (https://www.juznevesti.com/Drushtvo/ Urgentni-centar-se-selio-u-novovi-Klinicki -uz-trubace-video.en.html).
} 
This matrix of wedding customs automatically extends not only to events of no particular significance, but also to those events which are mournful in their nature, such as funerals, parastoses (parastos - an Orthodox memorial service for the departed). Serbian funeral rites and parastoses are not much different from wedding feasts in their rich and abundant meals (appetizers, soups, main courses, and desserts), and sometimes even in singing (usually under the influence of alcohol). "Death-related customs require a lot. Abundance of food and alcohol should be prepared considering the fact that all people present at the funeral ceremony are expected to attend a lunch afterwards. It is customary for this post-funeral lunch to be served three times that day for three different groups of people who attended the funeral. Guests drink and eat that day as if they are attending a joyful event and not an event of sadness and mourning. This custom has become so distorted that a Serbian Orthodox man has to rent a tavern. A special tavern called "Parastos" was opened in Niš, near the city cemetery." (Đorđević 2016, 107). All Souls' Day and all other funeral rites follow the same pattern of cultural behavior, which confirms the clergy's regular dissatisfaction with such indecent customary behavior. Members of the clergy hold an opinion that this abundance of food, drinks and artificial flowers at cemeteries is completely unnecessary and counterproductive (Obradović, Jovanović 2015,185 ) and is so exaggerated in its nature that it seems that the only thing missing there is "bird's milk" (Petrović, Jovanović 2015: 184). Care is also taken to commemorate the personal taste and preferences of the deceased, the type of food and all other things that person liked most during their lifetime.

\section{CONCLUSION}

The original purpose of the wedding gifts was to financially assist the newlyweds, but over time, this custom has deviated into its opposite - the newlyweds should "honor" the guests (relatives, friends, neighbors, acquaintances) by organizing a celebration of their marriage. What is evidently missing is a rational, sober approach in realistically evaluating the significance and character of an event and organize it in accordance with one's own financial means and the level of significance of the event itself. Serbs like to take pride in their 'hospitability', while in fact they often lack the hospitable approach frugality, responsibility, moderation. Although traditional Serbian weddings and all other festivities (family, personal, religious and national) have undergone significant transformation and cultivation during the period of transition, or rather modernization of Serbian society, they still retain considerable remnants of the past and pagan spirit with inevitably accompanying and recognizable immodesty and inappropriateness. In the words of the well-known Serbian columnist Ljubodrag Stojadinović: "This is who we are, only in pagan bacchanalia do we stop being poor, be it at slavas, weddings or funerals. At least for one day. And the future is of no immediate importance". 9

\footnotetext{
9 Stojadinović Ljubodrag, https://pescanik.net/strogo-kontrolisane-crkotine/?fbclid=IwAR344_UY1JczUJxc _Y9NAr5ARvGRlmwq_cuJGKab0t0zcw0V3ufWlPwUVes
} 


\section{REFERENCES}

Bigović R. Crkva i društvo. Beograd: Hilandarski fond pri Bogoslovskom fakultetu, 2010.

Bovan Vladimir. "Uticaj sveštenstva na izmene svadbenih običaja krajem XIX i početkom XX veka, prema zapisima Dene Debeljakovića”. U Kosovo i Metohija u svetlu etnologije, uredila Mirjana Menković, 123149. Beograd: Etnografski muzej u Beogradu, 2004.

Vlajković Ivana and Dušan, Stamenković. "Wedding Customs in the Village of Božica". In Religion, Religious and Folk Customs on the Border, edited by Dragoljub B. Đorđević, Danijela Gavrilović, and Dragan Todorović. Niš: YSSSR, 2012.

Vukanović Tatomir. Enciklopedija narodnog života, običaja i verovanja Srba na Kosovu i Metohiji (VI vek početak XX veka). Beograd: Vojnoizdavački zavod i Verzal press, 2001.

Marković Marija and Danijela Gavrilović. "Cult Places in the Babušnica Region”. In Cult Places on the Border, edited by Dragoljub B. Đorđević, Dragan Todorović and Dejan Krstić. Niš: YUNIR and Faculty of Mechanical Engineering at the University of Niš, 2014.

Đorđević B. Dragoljub. "The Roma of Serbia (Past - Present - Future)". In Roma Religious Culture, edited by Dragoljub B. Đorđević. Niš: YUNIR, 2003.

Đorđević B. Dragoljub, and Vladan Petrović. "Sirovari of Cakanovac". Religion, Religious and Folk Customs on the Border, edited by Dragoljub B. Đorđević, Danijela Gavrilović, and Dragan Todorović. Niš: YSSSR, 2012.

Đorđević B. Dragoljub, Slavoljub Uzunović i Vladan Petrović. Sirovo borovo (sociološka geneza preševskog Cakanovca). Novi Sad i Niš: Prometej i Mašinski fakultet u Nišu, 2014.

Đorđević B. Dragoljub. "Naš komšija pravoslavac”. U Džepna sociologija. Novi Sad: Prometej, 2016.

Jovanović, Bojan. "Krsna slava". U Privatni život Srba u devetnaestom veku, uredili Ana Stolić i Nenad Makuljević. Beograd: Clio, 2006.

Jovanović, Bojan. Prkos i inat (etnopsihološke studije). Beograd: Zavod za udžbenike, 2008.

Jovanović Bojan. Rečnik javašluka. Novi Sad: Prometej, 2009.

Karadžić S. Vuk. Srpski rječnik. Beograd: Prosveta, 1969.

Marić, Jovan. "Kakvi smo mi Srbi”, Deo 3. U Upamet se Srbi: Mali priručnik za korekciju sopstvenih nesavršenosti. Novi Sad: Budućnost, 2009.

Marjanović Miloš. "Gastarbajterski tip sela". U Od putanje do autostrade (Spomenica Jovana Ćirića), uredili Dragoljub B. Đorđević, Andon Kostadinović i Ljubiša Mitrović R. Niš: JUNIR i Univerzitetska biblioteka "Nikola Tesla", 2010.

Marković Marija and Danijela Gavrilović. "Cult Places in the Babušnica Region”. In Cult Places on the Border, edited by Dragoljub B. Đorđević, Dragan Todorović and Dejan Krstić. Niš: YUNIR and Faculty of Mechanical Engineering at the University of Niš, 2014.

Milošević Radulović Lela and Dragana Stjepanović Zaharijevski. “The Celebration of Saint Georges Day at the Votive Cross in Vrtovac (Knjaževac)'”. In Cult Places on the Border, edited by Dragoljub B. Đorđević, Dragan Todorović and Dejan Krstić. Niš: YUNIR and Faculty of Mechanical Engineering at the University of Niš, 2014.

Miltojević Vesna i Danijela Voza. "Vašar u selu Crnajka - opština Majdanpek". U Vašar u pograničju istočne $i$ jugoistočne Srbije, uredili Dragoljub B. Đorđević, Dragan Todorović i Dejan Krstić. Novi Sad i Niš: Prometej i Mašinski fakultet u Nišu, 2014.

Obradović Neven and Marija Jovanović. "Cemeteries and Funeral Practices in Bosilegrad". In Cemeteries and Burial Customs on the Border, edited by Dragoljub B. Đorđević, Dragan Todorović and Danijela Gavrilović. Niš: YUNIR, 2015.

Petrović Jasmina and Zoran M. Jovanović. "A Contribution to the Interpretation of Burial Customs and Cemeteries in the Dimitrovgrad Municipality”. In Cemeteries and Burial Customs on the Border, edited by Dragoljub B. Đorđević, Dragan Todorović and Danijela Gavrilović. Niš: YUNIR, 2015.

Petrović, Sreten. Srpska mitologija: Antropologija srpskih rituala. Niš: Prosveta, 2000.

\section{SVADBA KAO OPŠTI OBRAZAC SLAVLJA KOD SRBA}

U ovom radu autor se bavi savremenom prazničnom kulturom srpskog naroda koja se ogleda $u$ različitim oblicima neracionalnosti - pre svega, neumerenosti, nekontrolisanosti, rasipništvu itd. Autor pokazuje kako svadba kao glavni srpski običaj postaje opšti obrazac svetkovanja i kako se taj model prenosi na sve druge praznike - kako privatne (porodične i lične) događaje tako $i$ one kolektivne tj. nacionalne $i$ lokalne svetkovine (verske, nacionalne i državne praznike).

Ključne reči: svadba, srpski narod, krsna slava, sahrana, neumerenost. 